\title{
HEAVY METALS CONCENTRATION IN SEDIMENT OF LLUTA RIVER BASIN
}

\author{
S. V. COPAJA*, F. J. MUÑOZ
}

Departamento de Química. Facultad de Ciencias. Universidad de Chile. Casilla 653 Ñuñoa, Santiago, Chile.

\begin{abstract}
Northern Chile is characterized by water scarcity. The Lluta River, located in the XV region of Arica and Parinacota, is the one of the main rivers in northern Chile. The elevated levels of metals and metaloids in the river reduce the agricultural productivity and variety of species can be cultivated within the valley, which are of great importance for the consumption of the inhabitants of the area.

Heavy metals in river bottoms may cause various effects on the water quality, as such the capacity to accumulate metals; levels of toxicity and metal stabilization in sediments have often been considered a pollution index of a territory.

In this work the concentrations of $\mathrm{Al}, \mathrm{Cu}, \mathrm{Fe}, \mathrm{Mn}, \mathrm{Mo}, \mathrm{Pb}$ and $\mathrm{Zn}$ from the pseudo-total and labile fraction of Lluta river sediments were studied. Samples from 10 sites along the river were collected. The sediments were characterized determining: $\mathrm{pH}$, electrical conductivity, organic carbon (OC), organic total carbon (OTC), available phosphorus and boron. Heavy metals were analyzed by Atomic Absorption Spectroscopy (AAS).

For the metals analyzed in the pseudo-total fraction, the highest concentrations found were: $\mathrm{Al}$ in the site $10,\left(17061 \mathrm{mg} \mathrm{kg}^{-1}\right)$ and Fe on site $6,\left(29898 \mathrm{mg} \mathrm{kg}{ }^{-1}\right)$. For the labile fraction, highest concentrations of metals were: Al in site $6\left(1079 \mathrm{mg} \mathrm{kg}^{-1}\right), \mathrm{Fe}$ in site $9,\left(275 \mathrm{mg} \mathrm{kg}^{-1}\right)$ and Mn in site $9\left(1578 \mathrm{mg} \mathrm{kg}^{-1}\right)$.

Using the Risk assessment code (RAC), the site 6 presents the greatest risk with high values of $\mathrm{Cu}, \mathrm{Mn}, \mathrm{Pb}$ and $\mathrm{Zn}$, followed by site 1 with high values of $\mathrm{Mn}, \mathrm{Cu}$ and $\mathrm{Zn}$, and site 9 with high values of $\mathrm{Mn}, \mathrm{Cu}$ and $\mathrm{Pb}$. On the other hand, the MacDonald PEC (probable effect concentration) and TEC (threshold effect concentration) toxicity criteria, showed that the sites 4 and 6 have levels above the TEC for $\mathrm{Cu}, \mathrm{Fe}, \mathrm{Pb}$ and $\mathrm{Zn}$, and levels above the PEC at six sites for $\mathrm{Mn}$.
\end{abstract}

Keywords: Lluta River, sediment, heavy metals. Risk assessment code (RAC), Threshold effect concentration (TEC), Probable effect concentration (PEC).

\section{INTRODUCTION}

Northern Chile is characterized by water scarcity. The Lluta River, located in the XV region of Arica and Parinacota, is the one of the main rivers in northern Chile (Figure 1) This River it originates in the pre-Andean foothills of the Parinacota Province, a few kilometers north of the border with Peru, and ends $4 \mathrm{~km}$ north of the city of Arica. The Lluta River basin begins at more than 3900 meters above sea level, at the confluence of Caracarani creek and the
Sulphur River, with an average flow of $2300 \mathrm{~L} \mathrm{~s}^{-1}$. Over $36 \mathrm{~km}$, the river runs in a southeasterly direction and then begins slowly to turn westbound at the height of Socoroma, and then to expand out of its canyon from Chironta, more than $70 \mathrm{~km}$ away from the sea. In this last stretch the first agricultural crops that use water from this River begin. Finally, the river flows into an estuary with an extensive beach a few kilometers from Arica, close to Villa Frontera. The estuary is a resting place for several species of migratory birds, such as gulls, shorebirds, and others. ${ }^{1}$

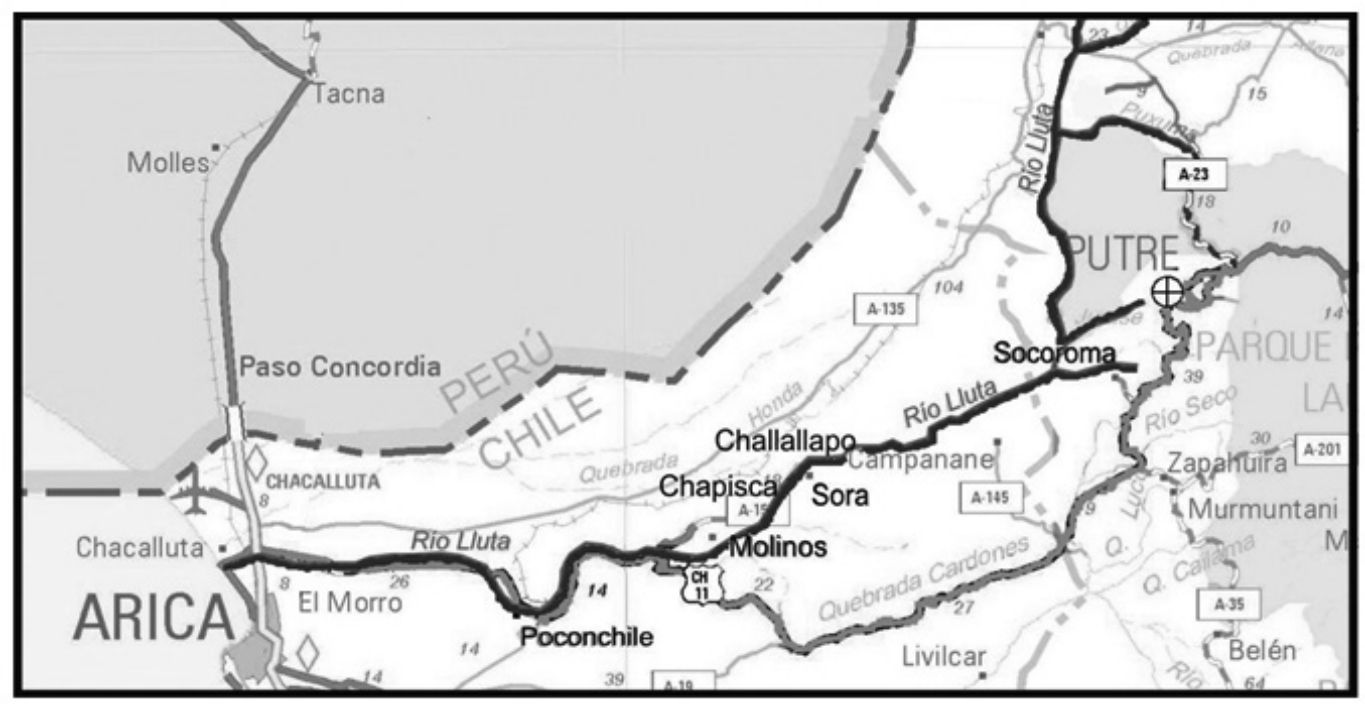

Figure 1. Lluta River basin.

In 2003 CONAMA, included this wetland in the list of 68 Priority Site for Conservation of Biodiversity in Chile, and subsequently by decree 106: 28 11-2009 the Ministry of Education declared the mouth of the Lluta River as a Nature Sanctuary Wetland. This wetland in a desert area enables the presence of abundant aquatic vegetation including of 130 bird species. The mouth of the Lluta River is frequented by waterfowl and land birds which feed and bathe, and is an important part of the life cycle of river shrimp and mullet. Moreover aquatic macrophytes vegetation supports an important biodiversity of aquatic insects and mollusks ${ }^{2-4}$.

This river presents high levels of electrical conductivity (EC) $>2 \mathrm{mS} / \mathrm{cm}$ ) boron concentrations $(0.1-0.6 \mathrm{mg} / \mathrm{L})$ and arsenic $(16-25 \mathrm{mg} / \mathrm{L}) .{ }^{5} \mathrm{High} \mathrm{EC}$ and arsenic (As) values are due, in part, to high levels of dissolved heavy metals, metalloids and sulfate discharged into surface waters in the upper sections of the valley. ${ }^{6}$ The elevated levels of these contaminants reduce the agricultural productivity and variety of species can be cultivated within the valley.7, 8 Agricultural products obtained are of great importance for the consumption of 
the inhabitants of the area.

Sediments are layers of finely divided material covering the bottoms of rivers, streams, lakes, reservoirs, bays, estuaries and oceans. ${ }^{9}$ Among the chemical species that can be found in sediment are heavy metals. The mobility of heavy metals depends on physical, chemical and biological processes, which are influenced by the mass exchange at the sediment-water interface. Concentration of metals within bottom sediments can consequently be 1-3 orders of magnitude greater than in the overlying surface water. ${ }^{10,11}$ However, the transport of heavy metal in rivers are reversible, accumulated heavy metals may be remobilized from sediments by natural processes and man-made changes in external parameters such as $\mathrm{pH}$, which may change due acid rain and complexing agents. ${ }^{12}$ Heavy metals in river bottoms may cause various effects on the water quality; because of this the capacity to accumulate metals, levels of toxicity and metal stabilization in sediments have been considered as a pollution index of a territory. ${ }^{13}$ Therefore, the analysis of heavy metals in sediments could indicate contamination that cannot be detected in water analysis and also provides information about critical areas in aquatic system. ${ }^{14-19}$ The study of heavy metals in water and sediments is important due to their toxicity, persistence and rapid accumulation by living organisms. Heavy metals not only will affect the environmental health of an aquatic system directly, they can also do so indirectly, by releasing pollutants into the water column, making them available to the organisms living in it. Under certain environmental conditions, heavy metals may accumulate to a toxic concentration, and cause ecological damage. ${ }^{20-21}$

In comparison with measurements of total metal concentrations, investigations of metal speciation in sediments are more important in providing sufficient information concerning their bioavailability and toxicity, as these characteristics are often dependent on chemical form or chemical species. ${ }^{22-24}$ Although it is possible to determine the concentration of total metals, recognizing environmental alterations via enrichment in the sediment, this does not provide information on the fraction available to the organisms. This fraction is composed of chemical forms that can incorporate metals to organism's food chains, where it is of paramount importance the quantification, control and treatment of these possible toxic agents. Depending on how available the metal is in solution, benthic organisms and microorganisms are able to capture it, ingesting it along with food and beginning to mobilize the metal through the trophic chain. ${ }^{25}$

Many researches have tried to create tables and indexes that refer to the level of toxicity of chemical species present in the sediments and their uptake into water. Currently, there are three indexes most often used for heavy metals. First, the Risk Assessment Code (RAC), which evaluates the availability of the metals in solution by the ratio between the soluble fraction and the total fraction in the sediment, which indicates the percentage that will pass to the water column. ${ }^{26,27}$ The second and third indexes are sediment quality standards for fresh water ${ }^{28}$ : TEC (threshold effect concentration) and PEC (probable effect concentration), making reference to the minimum concentrations of a metal considered toxic for the biota and another beyond which negative impacts are expected frequently.

The goal of this study was to determine the concentrations of seven heavy metals: $\mathrm{Al}, \mathrm{Cu}, \mathrm{Fe}, \mathrm{Mn}, \mathrm{Mo}, \mathrm{Pb}$ and $\mathrm{Zn}$, in the labile fraction of sediments (soluble, exchangeable or bonded to carbonate) and as a pseudo-total fraction in ten sites of Lluta River basin. Additionally, we estimated the possible ecological risk and toxicity level by calculating the risk assessment code (RAC), threshold effect concentration (TEC) and the probable effect concentration (PEC) for each site.

\section{MATHERIALS AND METHODS}

\subsection{Study area and description of the sites}

Ten sample sites were distributed along the River, beginning with a site upstream of Chacalluta Bridge and other stations downstream. Special attention was given to sampling the mouth of Lluta wetland. Sampling was conducted during a field campaign in October 2014. The sample sites are presented in Figure 2 .

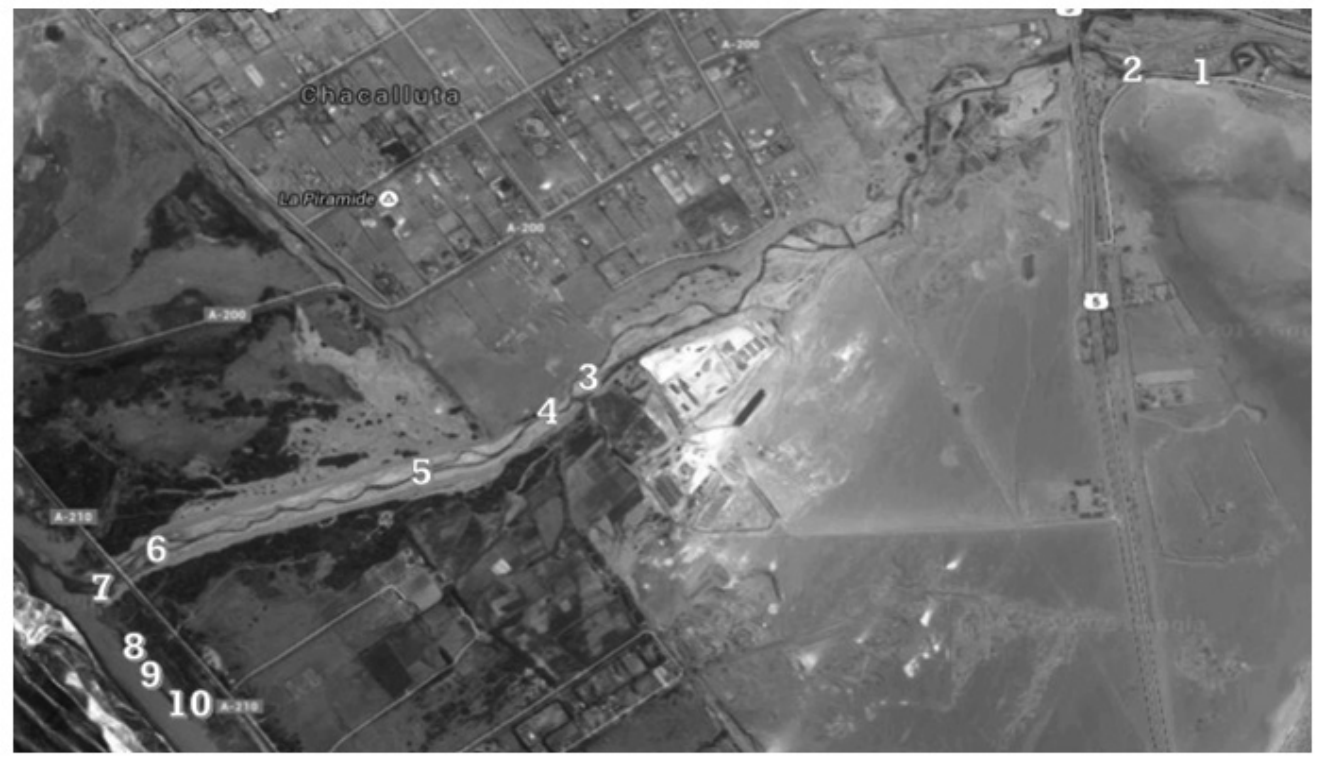

Figure 2. Sampling stations: 1: Pluviometric Station; 2. Chacalluta Bridge; 3: Santa Rosa Channel; 4: Santa Rosa Chanel; 5: Diatomite Plant; 6: Before the Mouth; 7: After the Mouth: 8, 9, 10: Wetland

\subsection{Sediment characterization}

In each site, samples of $1 \mathrm{~kg}$ of sediment were collected in polyethylene flasks according to the protocol of Simpson et al. (2005) ${ }^{28}$, which requires collecting samples with a plastic shovel from the top of the superficial sediment zone. Samples were brought to the laboratory and stored at $4{ }^{\circ} \mathrm{C}$. In the laboratory, samples were dry and sieve $<0.63 \mu \mathrm{m}, \mathrm{pH}$ and $\mathrm{CE}$ were measured by the potentiometric method. The Walkley-Black method was used to determine organic carbon content and available phosphorus was determined by the Olsen method. ${ }^{29,30}$ Boron was determined by the colorimetric method using azometine and total organic carbon (TOC) by the calcination method. ${ }^{30}$

\subsection{Heavy metals analysis}

The heavy metals analyzed in this study were: $\mathrm{Al}, \mathrm{Cu}, \mathrm{Fe}, \mathrm{Mn}, \mathrm{Mo}, \mathrm{Pb}$ and $\mathrm{Zn}$. The labile fraction of the sediments was obtained by stirring $0.25 \mathrm{~g}$ samples with $40 \mathrm{~mL}$ acetic acid (Merck p.a.) $0.11 \mathrm{~mol} \mathrm{~L}^{-1}$ for $16 \mathrm{~h}$, and then the samples were centrifuged at $3500 \mathrm{rpm}$ for $30 \mathrm{~min}$. In order to perform the digestions of the pseudo-total fraction of the metals microwave oven MarsXpress 5 was used, equipped with tubes of Teflon PFA of $55 \mathrm{~mL}$, protective sleeves of kevlar and an Xpress temperature sensor. This digestion allows greater control over the sample temperature and the heating rate than that of the heating plates. In this way, digestion facilitated in closed containers ensuring that the trace 
analyses are accurate and precise. The pseudo-total fraction was obtained by digesting $0.25 \mathrm{~g}$ of sediment with $10 \mathrm{~mL}$ of nitric acid (suprapur Merck) in a microwave oven (MarsX press) using the following conditions: power $800 \mathrm{~W}$; tower $100 \%$; time $11 \mathrm{~min}$.; temperature $175^{\circ} \mathrm{C}$, maintenance $15 \mathrm{~min}$.; cooling $15 \mathrm{~min}$. This was based on EPA method 3051 (Microwave-assisted acid digestion of sediments, sludge, soils, and oils $)^{31}$ finally, the samples were kept cold $\left(4{ }^{\circ} \mathrm{C}\right)$ for posterior analysis.

Standard solutions for heavy metals were prepared from Titrisol $1000 \mathrm{mgL}^{-1}$ (Merck); samples were analyzed using an atomic absorption spectrophotometer (AAS) (Shimadzu spectrophotometer 6800, ASC-6100). The following wavelength lines were used: $\mathrm{Cu}=324.7 \mathrm{~nm} ; \mathrm{Al}=309.3 \mathrm{~nm}$; $\mathrm{Fe}=248.3 \mathrm{~nm} ; \mathrm{Mn}=279.5 \mathrm{~nm} ; \mathrm{Pb}=217.0 \mathrm{~nm} ; \mathrm{Mo}=313.3 \mathrm{~nm}$ and $\mathrm{Zn}=$ $213.8 \mathrm{~nm}$.

\subsection{Analytical method validation and quality control}

To assure the accuracy of the data reported, recovery experiments were performed using standard reference material for sediments (BCR-320R). The concentrations ranges were based on the limit of detection (LOD) and the limit of quantification (LOQ) for each metal. The experiment was performed in triplicate using the sample from each site, and a calibration curve was obtained to see the linear relationship between absorbance and metal concentration in the dynamic range. The accuracy was measured in relation to coefficient of variation $(\mathrm{CV})$, finding that for all the measurements performed over different days the CV was less than $5 \%$. The method showed good accuracy with recovery values between $99 \pm 3$ and $104 \pm 1 \%$ in relation to the reference material, The LOQ of the metals in the total fraction was $\mathrm{Al}=0.063 ; \mathrm{Cu}=0.007 ; \mathrm{Fe}=0.54$; $\mathrm{Mn}=0.024 ; \mathrm{Mo} ;=0.0002 ; \mathrm{Pb}=0.402 ; \mathrm{Zn}=0.001$.

\subsection{Statistical analysis}

In this study the statistical analysis of the results was based on cluster analysis (CA). ${ }^{32} \mathrm{CA}$ was performed from original data in order to reduce the variant biases. The Furthest Neighbor method was applied and dissimilarly by city-Block distance. Statistical treatment of the data was carried out using R (version 2.15.2, The R Foundation for Statistical Computing)

\section{RESULTS AND DISCUSSION}

\subsection{Physical-chemical characterization of sediments.}

The following tables show the results obtained for the physicochemical characterization of the sediments of the Lluta River basin.

Table 1. Summary of the chemical characteristics measured in sediments. Each measurement was performed in duplicate, with their respective standard deviation $(\mathrm{SD})$.

\begin{tabular}{|c|c|c|c|c|c|c|}
\hline Sites & $\mathrm{pH}\left(\mathrm{H}_{2} \mathrm{O}\right)$ & $\mathrm{CE}\left(\mathrm{mS} \cdot \mathrm{cm}^{-1}\right)$ & $\mathrm{P}\left(\mathrm{mg} \cdot \mathrm{Kg}^{-1}\right)$ & $\mathrm{B}\left(\mathrm{mg} \cdot \mathrm{Kg}^{-1}\right)$ & $\mathrm{OC}(\%)$ & $\mathrm{TOC}(\%)$ \\
\hline 1 & $7.31 \pm 0.02$ & $2.34 \pm 0.04$ & $7.91 \pm 0.08$ & $7.38 \pm 0.01$ & 0.26 & 1.37 \\
\hline 2 & $7.75 \pm 0.01$ & $1.27 \pm 0.02$ & $6.78 \pm 0.03$ & $8.33 \pm 0.07$ & 0.13 & 0.60 \\
\hline 3 & $7.65 \pm 0.05$ & $0.82 \pm 0.03$ & $4.49 \pm 0.01$ & $6 . .85 \pm 0.02$ & 0.25 & 0.33 \\
\hline 4 & $7.23 \pm 0.02$ & $2.44 \pm 0.01$ & $8.28 \pm 0.05$ & $11.85 \pm 0.01$ & 0.40 & 1.22 \\
\hline 5 & $7.38 \pm 0.05$ & $1.44 \pm 0.04$ & $11.22 \pm 0.02$ & $4.61 \pm 0.08$ & 0.20 & 1.11 \\
\hline 6 & $7.60 \pm 0.02$ & $7.34 \pm 0.05$ & $13.92 \pm 0.05$ & $37.78 \pm 0.03$ & 0.47 & 1.22 \\
\hline 7 & $7.37 \pm 0.05$ & $2.37 \pm 0.02$ & $9.26 \pm 0.05$ & $9.56 \pm 0.09$ & 0.07 & 0.41 \\
\hline 8 & $8.71 \pm 0.02$ & $12.17 \pm 0.06$ & $7.67 \pm 0.01$ & $76.34 \pm 0.02$ & 0.34 & 1.40 \\
\hline 9 & $7.40 \pm 0.02$ & $2.54 \pm 0.01$ & $18.28 \pm 0.09$ & $6.29 \pm 0.04$ & 0.27 & 1.02 \\
\hline 10 & $7.40 \pm 0.03$ & $4.00 \pm 0.04$ & $9.32 \pm 0.03$ & $14.23 \pm 0.01$ & 1.21 & 3.18 \\
\hline
\end{tabular}

In table 2 , it is possible to observe that in sites $1,4,5$ and 7 has a neutral $\mathrm{pH}$ value, the sites $2,3,6,9$ and 10 are moderately basic and the site 8 is slightly alkaline. The lowest $\mathrm{pH}$ corresponds to the site 4 with a value of 7.23 and the highest corresponds to the site 8 with a value of 8.71 , this results is similar to values found in other basins. ${ }^{33}$

Sediment acidity determines the availability of metals in solution; most metals tend to be more available in acid media because of the absence of hydroxicomplex, which precipitates at basic $\mathrm{pH} .{ }^{34}$ However, As and Mo are exceptions since they are more available in alkaline media. Furthermore studies on heavy metals have revealed that at levels of moderately basic $\mathrm{pH}$ (i.e.: between 6 and 8) a higher percentage of metals are adsorbed. ${ }^{35}$ In this case, the neutral or slightly alkaline $\mathrm{pH}$ could mean that metals are less available to water and adsorbed in the sediment.

Based on electrical conductivity (EC) it can be inferred that sites 2, 3 and $5\left(0.82\right.$ to $\left.1.44 \mathrm{dSm}^{-1}\right)$ are not saline, sites $1,4,7,9$ and 10 (2.34 to 4.00 $\left.\mathrm{dSm}^{-1}\right)$ are slightly saline, 6 site $\left(7.34 \mathrm{dSm}^{-1}\right)$ is moderately saline and site 8 $\left(12.17 \mathrm{dSm}^{-1}\right)$ is very saline. Higher electrical conductivity is due to greater concentrations of dissolved salts, which may be due to contamination of effluent from surrounding industries, urban areas or natural conditions.

The Lluta River presents high levels of salinity (electrical conductivity (EC) $>2 \mathrm{mS} / \mathrm{cm}$ ). High EC and arsenic values are due, in part, to high levels of dissolved heavy metals and metalloids discharged into the surface waters in the upper sections of the valley. ${ }^{33}$

The highest percentages of easily oxidizable organic carbon (OC) and tota organic carbon (TOC) correspond to the site 10 , with values of $1.21 \%$ and $3.18 \%$ respectively. The lowest concentrations correspond to the site 7 for OC $=0.07 \%$ and site 3 for $\mathrm{TOC}=0.33 \%$. The highest content of $\mathrm{OC}$ was found at the site 10 which may be due to the accumulation of sediment in the wetland. Here the flora and fauna is wide and varied, contributing organic waste to the sedimentation at this site. Furthermore, this last OC measurement likely has a greater accumulation due to the movement of streams which end in the southern sector of the wetland. Importantly, organic carbon affects the distribution of metals, since these may be retained or complexed chelates. As such, a higher percentage of carbon could mean a lower concentration of available metals retained in the sediment and vice versa. In addition, the degradation of organic carbon may cause a shift to a more acidic $\mathrm{pH}$

The highest amounts of phosphate were found at sites 9,6 and 5, which correspond to mesotrophic sites, while sites 8,2 and 3 had lower measurements of phosphate and can be considered oligo mesotrophic and ultra-oligotrophic sites. The content of available phosphorus in the sediment is an indicator of water quality, because it is directly related to the availability of this element in the water column. High levels of this nutrient can lead to problems of eutrophication in the system. If found in excess, $\mathrm{P}$ contributes to the formation of sparingly soluble compounds or complexes with heavy metals as Al and $\mathrm{Fe}$. The high value of phosphorus found on the site 9 is due to the wetland in which the sample was taken, where vegetation comprises a varied ecosystem. Considering the character of phosphorous a macronutrient, this high value is consistent with the values of OC determined (table 1 ). High vegetation levels at Sites 6 and 5 indicated the possibility of high levels of phosphorus, which were corroborated by the analysis.

In the case of boron, sites 8,6 and 10 have high levels and lower values were found in sites 3,9 and 5. Boron is an essential micronutrient for normal plant development. ${ }^{35}$ Mainly, boron enters the environment weathering of rocks with boron or from sea water in vapor form of boric acid, but it also has an anthropogenic source through the use of boron-containing fertilizers and herbicides, the burning of plant products such as wood, coal or oil, and the generation of waste from the extraction and processing of borates. Organic boron is an important fraction of the total boron, and in general, samples with the most organic matter have a higher amount of boron, in this case: sites 4,6 , 8 and 10. High of boron levels are indicative of the location of the sediment, in 
this case, before the mouth of the river and the wetland. In general it has been found that numerous micronutrients, including boron, have a low concentration threshold which is useful. Under this threshold plants can show abnormalities due to deficiency and toxicity by excess.

The elevated levels of boron in the Lluta River reduce the agricultural productivity and the variety of species that can be cultivated within the valley. In addition, agricultural soils also present high concentration of boron because of the deposition of soluble boron from irrigation water which comes from the river and groundwater further restricting agricultural activities ${ }^{2}$.

\subsection{Concentration of heavy metals in sediments}

\subsubsection{Pseudo-total fraction}

Of the seven metals considered in the study (table 2), only six were found Molybdenum was under the limit of detection ( $<$ LOD).

Table 2. Al, $\mathrm{Cu}, \mathrm{Fe}, \mathrm{Mn}, \mathrm{Pb}$ and $\mathrm{Zn}$ concentrations $\left(\mathrm{mgkg}^{-1}\right)$. Each value is the mean of three samples. $\mathrm{SD}=$ standard deviation. $\mathrm{LF}$ (labile fraction); TF (total fraction).

\begin{tabular}{|c|c|c|c|c|c|c|c|c|c|c|c|c|}
\hline & \multicolumn{2}{|c|}{ Al } & \multicolumn{2}{|c|}{$\mathrm{Cu}$} & \multicolumn{2}{|c|}{$\mathrm{Fe}$} & \multicolumn{2}{|c|}{ Mn } & \multicolumn{2}{|c|}{$\mathbf{P b}$} & \multicolumn{2}{|c|}{ Zn } \\
\hline Sites & $\mathrm{LF}$ & $\mathrm{TF}$ & LF & $\mathrm{TF}$ & $\mathrm{LF}$ & $\mathrm{TF}$ & $\mathrm{LF}$ & $\mathrm{TF}$ & $\mathrm{LF}$ & $\mathrm{TF}$ & $\mathrm{LF}$ & $\mathrm{TF}$ \\
\hline 1 & $550 \pm 3.0$ & $11731 \pm 200$ & $17 \pm 0.4$ & $54 \pm 0.2$ & $146 \pm 2.0$ & $16076 \pm 100$ & $950 \pm 4.0$ & $1295 \pm 10$ & $19 \pm 4.0$ & $71 \pm 10$ & $73 \pm 0.8$ & $184 \pm 7.0$ \\
\hline 2 & $396 \pm 0.0$ & $14428 \pm 300$ & $33 \pm 0.3$ & $112 \pm 0.8$ & $72 \pm 2.0$ & $14294 \pm 500$ & $898 \pm 0.1$ & $3215 \pm 1.0$ & $10 \pm 4.0$ & $55 \pm 3.0$ & $60 \pm 0.5$ & $211 \pm 4.0$ \\
\hline 3 & $331 \pm 5.0$ & $14302 \pm 100$ & $13 \pm 0.6$ & $49 \pm 2.0$ & $15 \pm 0.8$ & $19670 \pm 400$ & $177 \pm 3.0$ & $527 \pm 10$ & $22 \pm 3.0$ & $81 \pm 3.0$ & $36 \pm 0.9$ & $184 \pm 20$ \\
\hline 4 & $481 \pm 15$ & $13863 \pm 900$ & $7 \pm 0.1$ & $38 \pm 0.8$ & $138 \pm 2.0$ & $26830 \pm 200$ & $97 \pm 2.0$ & $354 \pm 1.0$ & $15 \pm 5.0$ & $41 \pm 30$ & $31 \pm 0.6$ & $211 \pm 3.0$ \\
\hline 6 & $1078 \pm 10$ & $12609 \pm 800$ & $31 \pm 0.8$ & $81 \pm 2.0$ & $123 \pm 0.1$ & $29898 \pm 900$ & $964 \pm 0.1$ & $2517 \pm 50$ & $27 \pm 9.0$ & $58 \pm 7.0$ & $130 \pm 0.5$ & $361 \pm 40$ \\
\hline 7 & $456 \pm 10$ & $11355 \pm 60$ & $11 \pm 0.2$ & $44 \pm 0.2$ & $24 \pm 0.9$ & $15284 \pm 300$ & $814 \pm 4.0$ & $2938 \pm 0.4$ & $11 \pm 3.0$ & $71 \pm 7.0$ & $64 \pm 2.0$ & $200 \pm 20$ \\
\hline 8 & $198 \pm 8.0$ & $13550 \pm 600$ & $22 \pm 0.6$ & $61 \pm 0.4$ & $12 \pm 0.1$ & $11654 \pm 200$ & $317 \pm 5.0$ & $1459 \pm 30$ & $18 \pm 5.0$ & $48 \pm 3.0$ & $22 \pm 2.0$ & $102 \pm 0.5$ \\
\hline 9 & $479 \pm 8.0$ & $14177 \pm 100$ & $29 \pm 0.2$ & $67 \pm 1.0$ & $275 \pm 2.0$ & $19934 \pm 700$ & $1577 \pm 20$ & $2333 \pm 30$ & $22 \pm 4.0$ & $68 \pm 10$ & $35 \pm 3.0$ & $178 \pm 50$ \\
\hline 10 & $256 \pm 10$ & $17061 \pm 400$ & $11 \pm 0.0$ & $56 \pm 0.6$ & $238 \pm 7.0$ & $12314 \pm 70$ & $82 \pm 0.1$ & $228 \pm 0.7$ & $18 \pm 0.0$ & $71 \pm 7.0$ & $23 \pm 0.8$ & $115 \pm 0.5$ \\
\hline
\end{tabular}

Aluminum concentrations in the total fraction were found in greater values at sites 10,5 and 2, and lower values at sites 6,1 and 7. Iron concentrations were higher in sites 6,4 and 9, while lower concentrations were found in sites 5, 10 and 8. High levels of manganese were found at sites 2, 7 and 6, and lower concentrations were found at sites 4,5 and 10. The higher content is likely associated with an anthropic effect, as naturally, this element has only an abundance of $0.10 \%$. However, there are numerous studies showing the abundance of this element in river systems. ${ }^{36}$

Table 2 shows that $\mathrm{Zn}$ was found in high concentrations at all sites. Zinc was present in the highest concentration at site 6 , compared to other places sampled. Lower concentrations were found at sites 10,8 and 5; the latter was much lower regarding other Lluta River sites. Copper and lead varied depending on each site, but tended to remain relatively constant in relation to zinc. Copper had the highest values at sites 2, 6 and 9 and the lowest in 7,4 and 5. Lead had the highest values at sites 3, 7 and 10 and the lowest at sites 8, 5 and 4 . The values of lead found were relatively low, indicating little human intervention.

The analysis of pseudo-total fraction of heavy metals in other rivers of Chile (Choapa, Cachapoal, Aconcagua), In general it is possible to observe that the values found in the others river are relatively similar to the values found in Lluta River. ${ }^{37}$

\subsubsection{Labile fraction.}

The metals present (table 2), in sediment can be found in various chemical forms. However, the soluble or labile fraction is the most important since it is from this fraction which metals can be mobilized into the water column.

As in measurements of total metals of the seven elements studied, only six were found in the labile fraction; molybdenum was under the detection limit (<LOD). Table 2 shows that both manganese and aluminum were largely available. Manganese showed high values at sites 9,6 and 1. Sites with higher amounts of aluminum corresponded to 6,1 and 4, whereas those with lower amounts 10,8 and 5 . Unlike in the samples of total metals where iron was found in a high concentration, this element was less available. Sites with higher iron concentrations were 9,10 and 1 , and the lowest concentrations were found in 3, 8 and 5. Low iron availability was the result of increased $\mathrm{pH}$, conditions in which soluble iron decreases. At a pH close to 2 the amount of Fe (III) begins to decrease in solution, which occurs in conjunction with Al. Acetic acid used in the extraction of this fraction had a $\mathrm{pH}$ of approximately 2.9 , to be consistent with the low availability of these metals. $\mathrm{Zn}$ had higher concentrations at sites 6,1 and 7 and lower concentrations at 10,8 and 5. While this element is soluble at $\mathrm{pH}$ below 7 , the low concentration could be explained by the presence of oxides and organic matter. In the measurement of soluble $\mathrm{Zn}$, acetic acid was not capable of completely destroying organic matter or oxides which could retain this metal, limiting detection in the measured $\mathrm{pH}$ range. The highest availability of copper was measured at sites 2, 6 and 9 and less was available at 10,4 and 5. The presence of inorganic binders plays a more important role than organic binders in both the chemical retention and the complexing of copper.

The analysis of heavy metals in labile fraction of other rivers in Chile has produced similar results these measurements are similar to the values found in Lluta River. ${ }^{37}$

\subsection{Risk assessment code (RAC).}

The risk assessment code (RAC) uses the percentage of metals that are exchangeable and associated with carbonates (labile fraction). In this fraction the metals are weakly bound to the sediment and imply greater environmental risk since they are more available to the aquatic system. The RAC was determined based on the percentage of the total metal content that was present in the first sediment fraction (labile fraction). Percentages of $1-10 \%$ represent low risk, $11-30 \%$ medium risk, $31-50 \%$ high risk and $>50 \%$ very high risk. ${ }^{22}$,

Table 3. Percent of total metals in the labile fraction in sediments of Lluta River basin. High and very high risk are displayed in bold.

\begin{tabular}{|c|c|c|c|c|c|c|}
\hline Sites & $\mathrm{Al}$ & $\mathrm{Cu}$ & $\mathrm{Fe}$ & $\mathrm{Mn}$ & $\mathrm{Pb}$ & $\mathrm{Zn}$ \\
\hline 1 & 4.69 & $\mathbf{3 1 . 4 8}$ & 9.08 & $\mathbf{7 3 . 3 6}$ & 26.76 & $\mathbf{3 9 . 6 7}$ \\
\hline 2 & 2.75 & 29.46 & 0.50 & 27.93 & 18.18 & 28.44 \\
\hline 3 & 2.31 & 26.53 & 0.08 & $\mathbf{3 5 . 5 9}$ & 27.16 & 19.57 \\
\hline 4 & 3.47 & 18.42 & 0.51 & 27.40 & $\mathbf{3 6 . 5 9}$ & 14.69 \\
\hline 5 & 1.09 & 8.23 & 0.07 & 17.75 & 24.39 & 14.11 \\
\hline 6 & 8.55 & $\mathbf{3 8 . 2 7}$ & 0.41 & $\mathbf{3 8 . 3 0}$ & $\mathbf{4 6 . 5 5}$ & $\mathbf{3 6 . 0 1}$ \\
\hline 7 & 4.01 & 25.00 & 0.16 & 27.71 & 15.49 & $\mathbf{3 2 . 0 0}$ \\
\hline 8 & 1.46 & $\mathbf{3 6 . 0 7}$ & 0.10 & 21.72 & $\mathbf{3 7 . 5 0}$ & 21.56 \\
\hline 9 & 3.38 & $\mathbf{4 3 . 2 8}$ & 1.38 & $\mathbf{6 7 . 6 0}$ & $\mathbf{3 2 . 3 5}$ & 19.66 \\
\hline 10 & 1.50 & 19.64 & 1.93 & $\mathbf{3 5 . 9 7}$ & 25.35 & 20.00 \\
\hline
\end{tabular}

As shown in table 3 , the percentages of available aluminum and iron have 
a predominantly low risk. The low availability of these metals is due to its low solubility at $\mathrm{pH}$ range of extraction (approx. 2.9), which prevented a significant soluble concentration. $\mathrm{Cu}, \mathrm{Mn}, \mathrm{Pb}$ and $\mathrm{Zn}$ were medium to high risk at most sites. The sites at the highest environmental risk were 1, 6, 9 and 10. There metals may be transferred to the water column, since higher metal values in the soluble fraction represent a greater percentage of the total concentration and are soluble at a greater range of $\mathrm{pH}$, which is also complemented by the oxygenation of the water.

In other studies we found similar results for $\mathrm{Al}$ and $\mathrm{Fe}$, which were observed in high concentrations in the mineralogical sediment fraction, while $\mathrm{Cu}, \mathrm{Mn}$ and $\mathrm{Zn}$ were bound to carbonates, organic matter or in the exchangeable fraction. ${ }^{37}$

\subsection{Toxicity indices, PEC and TEC}

TEC and PEC values are shown for five of the six heavy metals found in sediments, because there are not values for Al. The TEC value indicates the concentration below which adverse effects are expected to occur rarely and PEC value indicates the concentration above which adverse effects are expected to occur frequently. ${ }^{27}$

For Fe, TEC and PEC concentrations are 20000 and $40000 \mathrm{mg} \mathrm{kg}^{-1}$ respectively, so the concentration of $\mathrm{Fe}$ found in sediments (table2), indicates that sites 4 and 6 were above TEC values but below PEC values. Similarly for $\mathrm{Cu}, \mathrm{TEC}$ and PEC concentrations are 32 and $150 \mathrm{mg} \mathrm{kg}^{-1}$ respectively, so the concentration of $\mathrm{Cu}$ found in sediments (table 2) were all the sites above TEC values, but below PEC values. For Mn, TEC and PEC concentrations are 460 and $1100 \mathrm{mg} \mathrm{kg}^{-1}$, respectively, so the concentration of $\mathrm{Mn}$ found in sediments (table 2) indicates that the site 3 was only above TEC values, but the sites 1, 2, $6,7,8$ and 9 were above PEC values. For Pb, TEC and PEC concentrations are 36 and $130 \mathrm{mg} \mathrm{kg}^{-1}$, respectively, so the concentration of $\mathrm{Pb}$ found in sediments (table 2) for all sites were above TEC values, but below PEC values. For Zn, TEC and PEC concentrations are 120 and $460 \mathrm{mg} \mathrm{kg}^{-1}$ respectively, so the concentration of $\mathrm{Zn}$ found in sediments (table 2), indicates that the most of sites were above TEC values, except sites 5, 8 and 10. All the sites were below PEC values for $\mathrm{Zn}$. Of the five metals considered, $\mathrm{Cu}, \mathrm{Mn}$ and $\mathrm{Zn}$ were the elements which present the greatest toxicity based on the TEC and PEC analysis, to microorganisms in these aquatic systems.

\subsection{Cluster Analysis}

Three cluster analyses were conducted. In the first cluster analysis, the parameters considered were the physicochemical characteristics of sediment: $\mathrm{pH}, \mathrm{EC}$, OC, OTC, available $\mathrm{P}$ and $\mathrm{B}$ for each site. Furthermore, the concentrations of labile and total fraction of metals were analyzed in separate clustering to identify the relationships for each site and similarities between them.

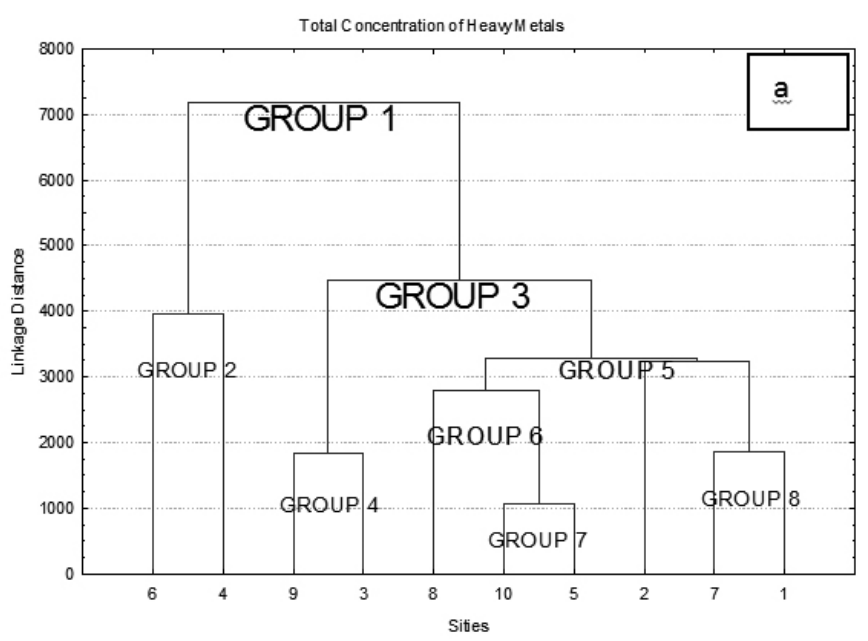

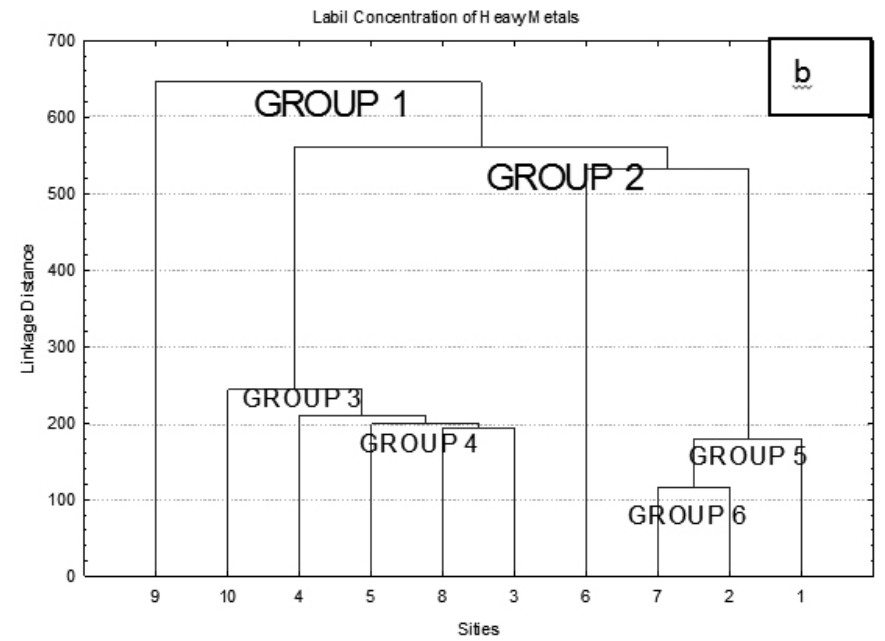

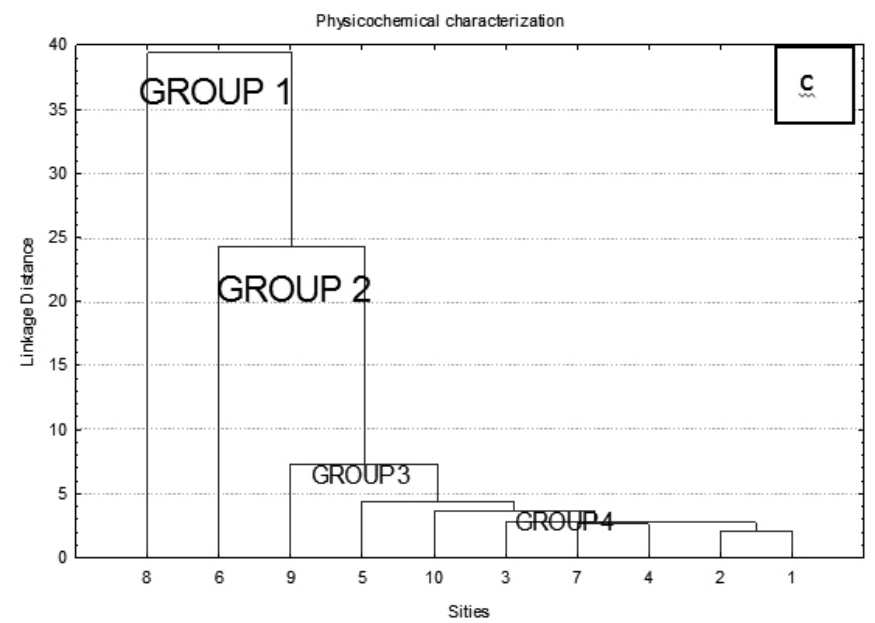

Figura 3. Dendrograms of Lluta River Basin, a) pseudo-total fraction of heavy metals, b) labile fraction of metals c) Physical and chemical characteristics.

Figure $3 \mathrm{a}$, shows eight groupings based on heavy metals concentration in the pseudo-total fraction. Group 7 represents has the greatest affinity among sites, in this case between sites 5 and 10. Overall, these groups does not show a large variation of concentrations compared. In group 2, sites 6 and 4 have less in common; leading up to group 1 and 3, where the Euclidean distance is greatest.

Figure $3 b$, shows six groups identified by similarities in the heavy metal concentrations of labile fraction. Group 1 and 2 shows that the sites 9 and 6 have very similar heavy metal concentrations in labile fraction. Following this group are groups 3, 4 and 5, considering sites 1, 10, 4, 5, 8 and 3 with similar characteristics. Overall, these groups do not show a large variation of concetrations compared. Groups 6 in sites 7 and 2 where the Euclidean distance is similar.

Figure $3 \mathrm{c}$, shows four groups that bring together the similarities of the sites on the basis of their physicochemical characteristics. Group 4, consists of the sites $10,3,7,4,2$ and 1 , and shows that the sites 1 and 2 have very similar physicochemical characteristics because their Euclidean distance in the dendrograms is close to zero. Sites 7 and 4 are the next closest pairing with similar characteristics. Overall, this group does not show wide variation in parameters compared. The Euclidean distance is much greater for groups 1, 2 and 3.

\section{CONCLUSIONS}

Sites 2 and 6 have the highest levels of $\mathrm{Cu}, \mathrm{Fe}, \mathrm{Mn} \mathrm{Zn}$ and $\mathrm{Al}$. These values may be explained because site 6 is located at the mouth of the river towards the wetland where heavy metals may accumulate, while site 2 is located near a railroad line.

The highest concentrations of labile metals were found at sites 
1, 6 and 9. These sites are located in the central sector of the wetland site 9, fluviometric station site 1 and the mouth of the river site 6 .

The levels of manganese along the river are worrisome. The indexes of MacDonald and RAC indicate a high level of danger for the biota of the river.

The site with the lowest amount of available metals in the labile fraction was 5. RAC and MacDonald indexes present a low risk for water and most metals are below or just above TEC, which would suggest that the site is non-toxic for biota.

Using the RAC code, the sites that present greatest risk are sites 1 and 6. On the other hand, using the toxicity levels of MacDonald, we found that sites 2 and 6 have levels $1 / 3$ above the TEC for $\mathrm{Cu}, \mathrm{Fe}, \mathrm{Pb}$ and $\mathrm{Zn}$, and six sites reach levels of the PEC for Mn (1, 2, 6, 7, 8 and 9).

Using cluster analysis, we can see that some sites have similar features, such as $1,2,3,4,5$ and 10 in terms of their physicochemical characteristics, while sites 9,8 and 6 are the most different. While in terms of total fraction of metals most of sites were similar and in terms of labile fraction sites 6 and 9 had the greatest Euclidean distance.

Special consideration should be given to the Lluta River as it feeds numerous irrigation channels used by the local agricultural sector. The findings of this study should be used to keep the river in optimal conditions, and provide the baseline for continued monitoring. Moreover, for the environmental care of the river's wetland habitat, the study of bird species is needed.

\section{ACKNOWLEDGMENTS}

The authors are grateful to the Departamento de Química. Facultad de Ciencias. Universidad de Chile.

\section{REFERENCES}

1. C.D.P. Ramila, E.D. leiva, C.A. Bonilla, P.A. Pasten, G.E. Pizarro J. Geochem. Exploration 150, 25 (2015).

2. Bahamonde, N. e I. Vila. Sinopsis sobre la biología del Camarón de Río del Norte. Biol. Pesq. Chile. 5, 3, 1971

3. Dyer, B.. Systematic review and biogeography of the freshwater fishes of Chile. Estudios oceanológicos (Chile) 19, 77 (2000).

4. Habit, E., Dyer, B. \&Vila, I. Estado de conocimiento de los peces dulceacuícolas de Chile. Gayana 70, 100 (2006).

5. Direccion General de Aguas (DGA), 2004. Diagnostico y clasificación de los cursos y cuerpos de agua según objetivos de calidad. Ministerio de Obras Públicas. Republica de Chile. Cuenca del Río Lluta6.

6. C. D. Leiva. P. Ramila, L.T. Vargas, C. R. Escauriaza, C.A. Bonilla, , J.M. Regan, P.A. Pasten. Sci. Total Environ. 466, 490 (2014).

7. F. Albornoz, A. Torres, M.I. Acevedo. Idesia (Arica) 25, 73 (2007).

8. A. Torres, E. Acevedo. Idesia (Arica) 26, 31 (2008).

9. S. E. Manahan. Environmental Chemistry, $6^{\text {th }}$ ed. Lewis Publishers: Chelsea, Boca Raton, USA, 1994; pp. 811.

10. J. M. Bubb JM, J.N. Lester JN Water, Air, and Soil pollut 78, 279 (1994).

11. S.V. Copaja, V.R.Nuñez, G.S. Muñoz, G.L. González, I.Vila I, D.E. Véliz J. Chil. Chem. Soc. 61 (2797). (2016).

12. W. Solomons, N.M.de Rooij, H.Kerdijk, J.Bril J (1987) Hydrobiologia 149, 13 (1987)

13. N. Riog, J. Sierra, I. Moreno-Garrido, E. Nieto, E. Pèrez, M. Shumacher, J. Blasco. Sci. Total Environ. 549, 287 (2016).

14. U. Förster, W. Solomons, Environm. Technol. Lett. 1, 494 (1980).

15 H.E. Belkin, H.M. Sparck, Environm Geol. 22, 106 (1993).

16. U. Förster Int. J. Environm. An. Ch. 51, 5 (1993).

17. J.T. W Chen, S.K. Tan, Water, Air and soil Pollut. 92, 273 (1996).

18. J. A. Narváez, P. Richter, m. I. Toral J. Chil. Chem. Soc. 52, 1261 (2007).

19. A. Kabata-Pendias, H. Pendias. Trace element in Soils and Plants 3erd ed. CRC Press: Boca Raton, FL USA (2001).

20. U. Förstner, W. Solomons. Envirom. Geol. 39, 90 (1999).

21. DGA (Dirección General de Aguas). Caracterización de Sedimentos Fluviales y su Relación con la Calidad del agua, 2008, pp 1-80

22. W. Calamano, J. Hong, U. Fosrstner. Water Science and Technology 28 , 223 (1993).

23. Orkun, I., Davutluoghlu, G. S., Demet, G. K., Turan, Y., G., Cagatayhan, B. F. Desalination 260, 199 (2010).

24. X-Y Wu, Y. F. Yang, Aquaculture Reserach, 41, 1377, (2010).

25. Ed. A. Passon, J. C. Alves, I. S. A. Dos Santos, J. P. H. Alves, C. A. B. Garcia, A. C. Spinola Costa, Microchem. J. 96, 50, (2010).

26. G. Perin, L. Craboleda, M. Lucchese, R. Cirillo, I. Dotta, I., M. Zanette,
Orio, Heavy metals speciation in the sediments of Northen Adriatic sea-a new approach for environmental toxicity determination: in Lekkas TD, editor: Heavy metal in the enviroment, 2010; pp. 45-46.

27. D. D. MacDonald, C. Ingersoll, T. Berger, Arch. Environ. Contam. Toxicol., 39, 20, (2000)

28. S. I. Simpson, G. E. Batley, A. A. S. Charlston, J. L. Dtauber, C. K. King, J. C. Chapman, R. V. Hyne, S. A. Gale, A. C. Roach, W. A. Maher, J. Sharyan. J, Handbook for Sediment Quality Assessment, (CSIRO Bangor, NSW), 2005; pp 9-19

29. L. C. Blackemore, P. L. Scarle, B. K. Daly, B. K. In Methods for Chemical of Analysis of Soils N. Z. Soil Bureau Scientific Report, 1987; pp 18-34

30. A. Sadzawka, M. A. Carrasco, R. Grez, M. L. Mora, H. Flores, A Neuman, A. Métodos de Análisis de Suelos. Instituto de Investigaciones Agropecuarias (INIA). Serie Actas INIA N 34 , 2006; pp 59-79E.D.

31. EPA Method 3051, Microwave assisted acid digestion of sediments, sludges, soils, and oils, 1994

32. Cluster analysis electronic Text Book statarSoft "Copyright StataSoft, in 1984-2004

33. DGA (Dirección General de Aguas). Caracterización de Sedimentos Fluviales y su Relación con la Calidad del agua, 2008, pp 1-80.

34. F. Burriel Marti, F. Lucena-Conde, S. Arribas-Jimeno, J. Hernadez Méndes. Química Analítica Cualitativa (Décimo Sexta Edición) (Editorial PARANINFO) Madrid, España. cap. XIX y XX, 2003.

35. C. A. B. Garcia, M. S. Barreto, E. A. Passos, J. Patrocínio, H. Alves, J. Braz. Chem. Soc. 20, 1334 (2009).

36. B. A. Schumacher, METHODS FOR THE DETERMINATION OF TOTAL ORGANIC CARBON (TOC) IN SOILS AND SEDIMENTS. U.S Environmental Protection Agency, Washington, DC, EPA/600/R-02/069 (NTIS PB2003-100822), 2002.

35. U. C. Gupta, Y.W. Jame, C.A. Campbell, A.J. Leyshon and W. Nicholaichuk, Can. J. Soil Sci., 65, 381 (1985).

36. S. V. Copaja, G. Díaz, R. Toro, R.M. Tessada, P. Miranda, J. R. Morales, J. Chil. Chem. Soc., 57, 1400 (2012)

37. S.V. Copaja, M. X. Molina, R.M. Tessada J. Chil. Chem. Soc., 58, 1986 (2014) 